\title{
Activation of CDK4 by Tax chemosensitizes p53-mutant cells to DNA damage
}

\author{
O John Semmes ${ }^{1,2^{*}}$, Xin Guo ${ }^{1,2}$, Valia T Mihaylova ${ }^{3}$, Gary M Kupfer ${ }^{3}$ \\ From 16th International Conference on Human Retroviruses: HTLV and Related Viruses \\ Montreal, Canada. 26-30 June 2013
}

Human T cell leukemia virus type 1 (HTLV I) Tax protein has been implicated in cellular transformation via perturbations in genomic stability, transcription, and the cell cycle, and is etiologically linked to the development of adult $\mathrm{T}$ cell leukemia and various human neuropathies. It has been established that Tax mediates an increase in cyclin D3-dependent CDK4 activity and we and others have demonstrated that expression of Tax correlates with hyperphosphorylation of retinoblastoma protein and activation of E2F transcription factors. In this study, we explore the relationship between TaxCDK4 binding and its activations. Although steady-state levels of CDK4 remained unchanged, the expression of Tax resulted in a reduction in the proportion of CDK4 bound in an inhibitory complex with Cyclin D3 and p27. Tax binding and CDK4 activation is mediated through the $\mathrm{N}$ terminal 25 amino acids, which we also show is sufficient to confer Tax chemosensitization of p53 mutant cells. The Tax-induced stimulation of CDK4 activity results in increased $\mathrm{S}$ phase percentage of cells under hypoxic and starvation stress conditions. A 25 amino acid peptide of Tax markedly stimulates CDK4 kinase activity in vitro and can chemosensitize p53 mutant cells as well. Our studies suggest a mechanism for chemosensitization of p53 mutant cells by exploiting Tax-mediated activation of CDK4.

\section{Authors' details}

'Department of Microbiology and Molecular cell Biology, Eastern Virginia Medical School, Norfolk, VA, USA. ${ }^{2}$ The Leroy T. Canoles Jr. Cancer Research Center, Eastern Virginia Medical School, Norfolk, VA, USA. ${ }^{3}$ Department of Pediatrics, Yale University, New Haven, CN, USA.

Published: 7 January 2014

\footnotetext{
*Correspondence: Semmesoj@evms.edu

'Department of Microbiology and Molecular cell Biology, Eastern Virginia Medical School, Norfolk, VA, USA

Full list of author information is available at the end of the article
}

doi:10.1186/1742-4690-11-S1-O44

Cite this article as: Semmes et al:: Activation of CDK4 by Tax

chemosensitizes p53-mutant cells to DNA damage. Retrovirology 201411 (Suppl 1):O44.
Submit your next manuscript to BioMed Central and take full advantage of:

- Convenient online submission

- Thorough peer review

- No space constraints or color figure charges

- Immediate publication on acceptance

- Inclusion in PubMed, CAS, Scopus and Google Scholar

- Research which is freely available for redistribution

Submit your manuscript at www.biomedcentral.com/submit

\section{() Biomed Central}

C Biomed Central

(c) 2014 Semmes et al; licensee BioMed Central Ltd. This is an Open Access article distributed under the terms of the Creative Commons Attribution License (http://creativecommons.org/licenses/by/2.0), which permits unrestricted use, distribution, and reproduction in any medium, provided the original work is properly cited. The Creative Commons Public Domain Dedication waiver (http://creativecommons.org/publicdomain/zero/1.0/) applies to the data made available in this article, unless otherwise stated. 